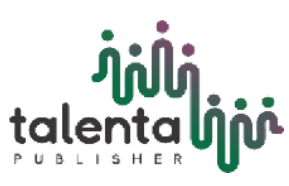

Jurnal Dinamis

Vol. 9, No. 1, Bulan Tahun | 06-21

ISSN : 0216-7492, e-ISSN : 2809-3410

Homepage : https://talenta.usu.ac.id/dinamis

\title{
STUDI EKSPERIMENTAL TEGANGAN-REGANGAN PADA CONNECTING JOINT ALAT PEMANEN KELAPA SAWIT MENGGUNAKAN MODUL AKUSISI BF 350 AA
}

\author{
Mailando Sitanggang ${ }^{*}$, Muhammad Sabri ${ }^{2}$, Arif Fadillah Nasution ${ }^{3}$ \\ Departemen Teknik Mesin, Fakultas Teknik, Universitas Sumatera Utara \\ Jalan Dr. T. Mansyur No. 9, Padang Bulan, Kec. Medan Baru, Kota Medan, Sumatera Utara 20222, Indonesia \\ *Email: mailandositanggang@ gmail.com
}

\begin{abstract}
ABSTRAK
Untuk mengatasi krisis energi masa depan, beberapa alternatif sumber energi sudah banyak dikembangkan, salah satunya adalah energi matahari, energi matahari dapat digunakan menjadi sumber energi panas yang pemanfaatannya sudah sangat banyak digunakan, salah satunya adalah pada mesin pendingin siklus adsorpsi. Mesin pendingin siklus adsorpsi adalah suatu alat yang digunakan untuk mendinginkan sesuatu misalnya seperti buah-buahan, air, vaksin dan sebagainya dengan memanfaatkan sinar matahari untuk menjalankan siklusnya. Mesin pendingin siklus adsorpsi memiliki 3 komponen utama yaitu kolektor, kondensor, dan evaporator. Pada pengujian ini ketiga komponen utama tersebut terbuat dari bahan alumunium karena memiliki nilai konduktivitas thermal yang tinggi dan tahan terhadap korosi akibat dari air maupun refrijeran yang digunakan. Pasangan adsorben dan refrijeran yang digunakan adalah karbon aktif serbuk sebanyak 10 $\mathrm{kg}$ dan metanol sebanyak 3 liter. Tujuan dari penelitian ini untuk mengetahui temperatur maksimum pada kolektor, temperatur minimum pada air yang di dinginkan, efesiensi kolektor dan nilai COP sistem. Prosedur pengujian dengan memanaskan kolektor surya (desorpsi) dari pukul 08.00 WIB - 17.00 WIB, sedangkan proses pendinginan alamiah (adsorpsi) berlangsung dari pukul 17.00 WIB - 08.00 WIB. Dari hasil pengujian dan perhitungan yang telah dilakukan didapat bahwa temperatur maksimum kolektor $126,56{ }^{\circ} \mathrm{C}$, temperatur minimum vaksin $-0,09^{\circ} \mathrm{C}$, efisiensi kolektor tertinggi 53,399 \% dan nilai COP tertinggi adalah 0,000956.
\end{abstract}

Kata kunci: Energi Surya, Mesin Pendingin, Adsorpsi, Desorpsi, Kolektor

\begin{abstract}
The connecting joint is a component designed to connect the stems 1, 2, and 3 of the oil palm harvester. In this study, the researcher analyzed the stress and strain on the connecting joint of the oil palm fruit harvesting device that had been designed by the palm tool harvesting team. This tool can be tilted according to the harvester's safe distance from the tree. The purpose of this study is to determine the value of stress and strain on a connecting joint and to know the percent error of the comparison of experimental test results with computational simulations. The benefit of this research is that it can determine the stress and strain values in the material by using the BF 350 AA module. The research method was carried out experimentally. The test procedure is carried out by attaching the strain gauge sensor to the point where the stress is greatest. From the results of the tests and calculations that have been carried out, the results show that the highest stress is $9.58 \mathrm{MPa}$, the lowest stress is $0 \mathrm{MPa}$, the highest strain is 0.000128 , the lowest strain is 0 , the maximum percentage error occurs at $90^{\circ}$ in automatic and manual joints, namely $100 \%$ and the minimum error occurs at joint manual hole 2 at a slope of $60^{\circ}$, the error percentage is reduced, equal to $2.74 \%$. From the results of the tests carried out, the connecting joint is safe to use in oil palm harvesters.
\end{abstract}

Keyword: Connecting joint, stress, Strain, Module BF 350 AA.

\section{PENDAHULUAN}

Salah satu faktor yang paling banyak mempengaruhi pertumbuhan dan produktivitas kelapa sawit ini adalah faktor panen. Untuk memenuhi kebutuhan panen ini dibutuhkan sebuah peralatan sebagai sarana penunjang pekerjaan dalam hal pemanenan buah kelapa sawit, maka perlu adanya suatu alat bantu pemanenan untuk mempermudah pekerjaan yang dilakukan dan tentunya dengan mempertimbangkan masalah kesehatan dan keselamatan kerja serta ramah terhadap lingkungan. Sebelumnya memang sudah 
ada inovasi-inovasi mengenai peralatan panen buah kelapa sawit ini, tetapi masih banyak terdapat kelemahan-kelemahan. Oleh sebab itu Peneliti akan menganalisa tegangan dan regangan yang terjadi pada connecting joint alat pemanenan buah kelapa sawit yang telah dirancang oleh tim harvesting palm tool dengan menggunakan sensor strain gauge dan modul BF 350 AA sebagai pembaca resistensinya.

Pada pembuatan alat pemanen kelapa sawit ini, tim merancang alat ini dengan sistem bongkar pasang. Dimana batang galah tersebut dibagi menjadi 3 batang. Batang yang pertama memiliki panjang 3 meter, batang yang ke 2 memiliki panjang 2 meter, batang yang ke 3 memiliki panjang 1 meter. Setiap batang tersebut di hubungkan oleh connecting joint. Connecting joint tersebut dibagi menjadi 2. Yang pertama adalah connecting joint yang menghubungkan batang satu dan batang dua. Connecting joint yang pertama ini dapat diatur secara manual kemiringannya dengan 3 lobang poros. Sedangkan connecting joint yang kedua adalah yang menghubungkan batang yang ke dua dengan batang yang ke tiga.

\section{TEORI DASAR}

\subsection{Sensor Strain gauge}

Strain gauge adalah bagian yang sangat penting dari sebuah load cell, dengan fungsi untuk mendeteksi besarnya perubahan dimensi jarak yang disebabkan oleh suatu elemen gaya. Strain gauge secara umum digunakan dalam pengukuran presisi gaya, berat, tekanan, torsi, perpindahan dan kuantitas mekanis lainnya dan dikonversi menjadi tegangan. Strain gauge menghasilkan perubahan nilai tahanan yang proporsional dengan perubahan panjang atau jarak (length). Gaya yang diberikan pada suatu benda logam, selain menimbulkan deformasi bentuk fisik juga menimbulkan perubahan sifat resistansi elektrik benda tersebut. Gambar 2.1 merupakan gambar sensor strain gauge

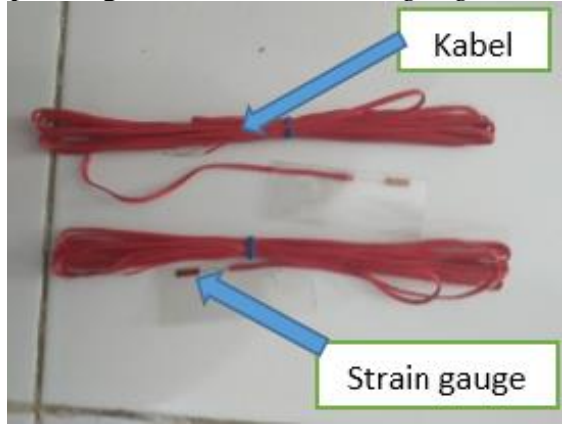

Gambar 2.1 Strain Gauge

\subsection{Jembatan Wheastone}

Jembatan wheastone adalah alat ukur yang ditemukan oleh Samuel Hunter Christie pada 1833. Alat ini digunakan untuk mengukur suatu yang tidak diketahui hambatan listrik dengan menyeimbangkan dua kali dari rangkaian jembatan, satu kaki yang mencakup komponen diketahui kerjanya mirip dengan aslinya potensiometer. Jembatan wheastone terdiri dari tahanan R1, R2, R3 dimana tahanan tersebut merupakan tahanan yang diketahui nilainya dengan teliti dan dapat diatur. Metode jembatan wheastone adalah susunan komponen-komponen elektronika yang berupa resistor dan satu daya.

Jembatan wheastone memiliki 3 jenis. Adapun jenis-jenis jembatan wheastone sebagai berikut: 1. Sirkuit seperempat jembatan (Quarter Wheatstone Bridge)

Susunan dengan elemen (sensor) tunggal pada jembatan wheastone disebut juga dengan quarter bridge strain gauge circuit seperti pada Gambar 2.2. Nilai tahanan pada (R1, R2 dan R3) disetel sama satu sama lain. dengan demikian, tanpa gaya yang diterapkan pada pengukur regangan, jembatan akan seimbang secara simetris dan voltmeter akan menunjukan nol volt.

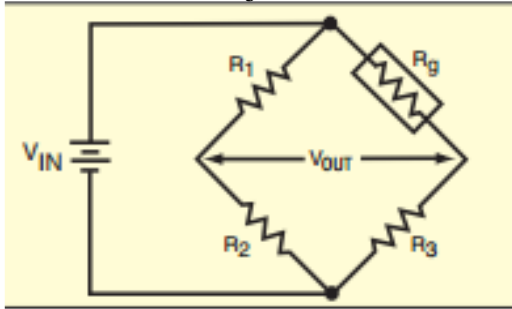

Gambar 2.2 Rangkaian Seperempat Jembatan Wheastone ${ }^{[7]}$

Susunan dengan elemen tunggal jembatan yang mengubah tahanan sebagai respon terhadap variabel terukur (gaya mekanis), dikenal sebagai sirkuit seperempat jembatan. Pada modul BF 350 AA menggunakan rangkaian seperempat jembatan untuk mendapatkan nilai regangan sebagai berikut ${ }^{[8]}$ : 


$$
V_{\text {out }}=V_{\text {in }}\left\{\frac{R_{3}}{R_{3}+R_{g}}+\frac{R_{2}}{R_{1}+R_{2}}\right\} \text {...... }
$$

Jika $(\mathrm{R} 1 / \mathrm{R} 2)=(\mathrm{Rg} / \mathrm{R} 3)$, maka Vout $=0$

Dimana :

Vout = Tegangan keluaran ADC

Vin = Tegangan yang masuk ke modul

$\mathrm{Rg}=$ Hambatan yang terjadi pada strain gauge

R1,2,3 = Hambatan yang terjadi di titik 1,2, dan 3

Dari persamaan (2.1) mempunyai hubungan antara Vout dengan Vin dimana dapat ditulis dengan persamaan ${ }^{[8]}$

$$
\frac{\text { Vout }}{\text { Vin }}=\left[\frac{R_{3}}{R_{3}+R_{g}}-\frac{R_{2}}{R_{1}+R_{2}}\right]
$$

Persamaan diatas berlaku untuk kedua kondisi disaat strained dan unstrained. Dalam menentukan nilai saat kondisi unstrained dari resistansi ialah nilai $\mathrm{Rg}$, nilai dari regangan resistensi adalah $\mathrm{Rg}+\triangle \mathrm{Rg}$ dimana persamaan (2.2) dihubungkan dengan persamaan $\triangle \mathrm{Rg} / \mathrm{Rg}$ mendapatkan persamaan:

$$
\frac{\Delta R g}{R g}=\frac{4 V r}{1+2 V r}
$$

Hubungan antara persamaan dengan persamaan akan menghasilkan persamaan regangan. Berikut uraian dari persamaan regangan ${ }^{[8]}$

$$
\varepsilon=\frac{4 V r}{G F(1+2 V r)}
$$

Dimana:

$$
\begin{aligned}
\varepsilon & =\text { Regangan } \\
\mathrm{GF} & =\text { Gauge Factor } \\
\mathrm{Vr} & =[(\text { Vout } / \text { Vin }) \text { strained }-(\text { Vout }- \text { Vin }) \text { unstrained }] \text { (volt) }
\end{aligned}
$$

2. Sirkuit setengah jembatan (Half Wheastone Bridge)

Susunan dengan memiliki dua elemen (sensor) pada jembatan wheastone sebagai pengukur untuk menanggapi ketegangan disebut juga dengan half bridge strain gauge circuit seperti pada Gambar 2.3 .

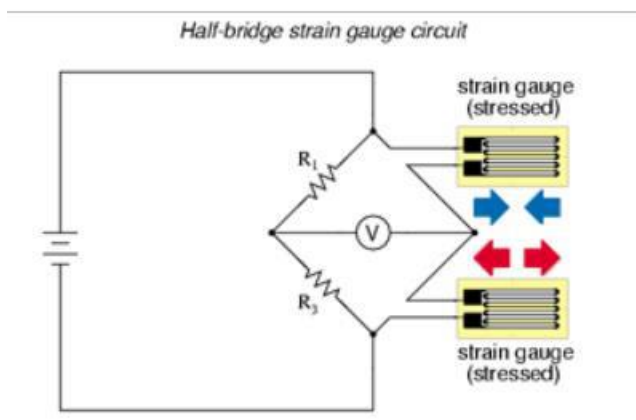

\section{Gambar 2.3 Rangkaian Setengah Jembatan ${ }^{[7]}$}

Karena kedua pengukur regangan akan meningkatkan atau menurunkan resistansi dengan proporsi yang sama sebagai respon terhadap perubahan suhu, efek perubahan suhu tetap dibatalkan dan sirkuit akan mengalami suhu minimum yang disebabkan oleh suhu.

3. Sirkuit jembatan Penuh (Full Wheastone Bridge)

Susunan dengan memiliki empat elemen (sensor) pada jembatan wheastone sebagai pengukur untuk menanggapi ketegangan disebut juga dengan Full bridge strain gauge circuit seperti pada Gambar 2.4.

$$
\text { Full-bridge strain gauge circuit }
$$

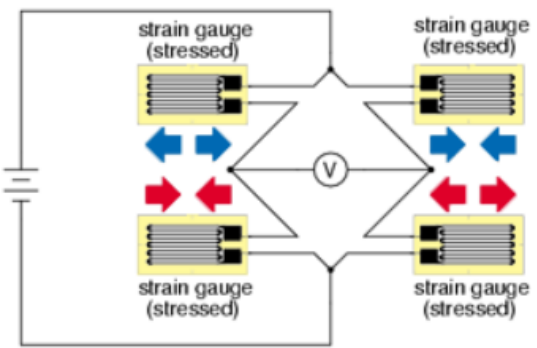

\section{Gambar 2.4 Rangkaian Jembatan Penuh Wheastone ${ }^{[7]}$}

Konfigurasi half-bridge dan full-bridge memberikan sensitivitas yang lebih besar pada sirkuit quarter-bridge. Konfigurasi jembatan penuh baik untuk digunakan karena lebih sensitif dan linear 
daripada yang lain, sirkuit quarter-bridge dan half-bridge memberikan sinyal output (ketidakseimbangan) yang hanya sebanding dengan gaya pengukur regangan yang diterapkan

\subsection{Tegangan dan regangan}

\section{Tegangan}

Tegangan adalah sebuah bentuk reaksi pada bagian dalam penampang benda akibat adanya gaya yang bekerja dari luar. Pengukuran tegangan yang paling sering digunakan adalah dengan menggunakan sensor strain gauge. Strain gauge merupakan sebuah sensor yang memanfaatkan regangan yang terjadi pada daerah grid foil-nya. Ketika strain gauge di ikatkan pada sebuah benda yang mengalami regangan, grid foil dari strain gauge juga ikut meregang. Akibat dari meregangnya grid foil tersebut mengakibatkan tahanan listriknya berubah, dan perubahan nilai tahanan (hambatan) listrik sebanding dengan nilai regangan yang terjadi pada benda.

\section{Regangan}

Regangan $\varepsilon$ disebut regangan normal karena regangan ini berkaitan dengan tegangan normal. Jika batang mengalami tarik maka regangan tersebut adalah regangan tarik, yang menunjukkan perpanjangan bahan. Hal tersebut juga terjadi jika batang mengalami tekan maka regangan tersebut adalah regangan tekan, dan batang tersebut akan memendek. Regangan tekan bertanda negatif dan untuk regangan tarik bertanda positif. Dalam kontek aplikasi, strain dihubungkan dengan deformasi dan dapat dimanfaatkan untuk mengukur strain dan deformasi yang dialami suatu elemen. Sensor yang dimanfaatkan fenomena tegangan-regangan yaitu strain gauge.

Adapun hubungan tegangan- regangan dapat dilihat dari persamaan hukum Hooke, yaitu untuk mencari nilai tegangan $(\sigma)$ ialah nilai regangan $(\varepsilon)$ dikalikan dengan nilai modulus elasitisitas bahan spesimen uji $(E)$, dalam hal ini adalah Alumunium yaitu $69000 \mathrm{MPa}$

$$
\sigma=\varepsilon . E
$$

\subsection{Modul BF 350 AA}

BF 350 AA adalah modul tegangan regangan, yang memiliki prinsip kerja mengkonversi perubahan yang terukur dalam perubahan resistansi dan mengkonversinya ke dalam besaran tegangan melalui rangkaian yang ada. Modul melakukan komunikasi dengan komputer atau mikrokontroler. Struktur yang sederhana, mudah dalam penggunaan, hasil yang stabil dan reliable, memiliki sensitivitas tinggi, dan mampu mengukur perubahan dengan cepat. Gambar 2.5 merupakan gambar modul BF 350 AA

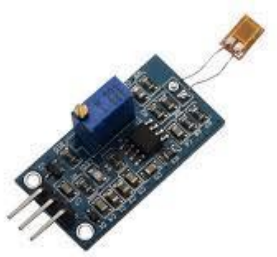

Gambar 2.5 Modul BF 350 AA ${ }^{[6]}$

\subsection{Arduino Uno}

Arduino merupakan sebuah microcontroller yang berfungsi sebagai data akuisisi pada penelitian ini. Arduino memiliki enam pin analog yang berfungsi sebagai penerima input sinyal analog dari rangkaian listrik. Pada penelitian ini, menggunakan empat saluran (channel) strain indicator. Arduino juga berfungsi sebagai pemasok tegangan voltage ke rangakaian jembatan wheatstone pada strain indicator. Gambar 2.6 merupakan gambar Arduino Uno

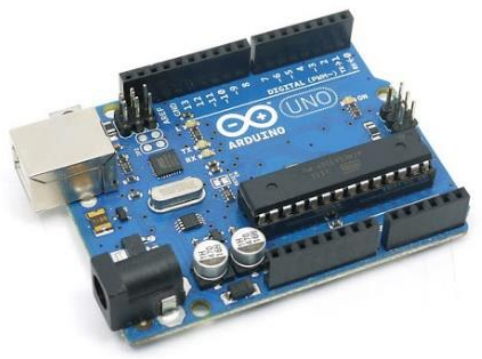

Gambar 2.6 Arduino Uno 


\section{HASIL DAN PEMBAHASAN}

\subsection{Set-Up alat}

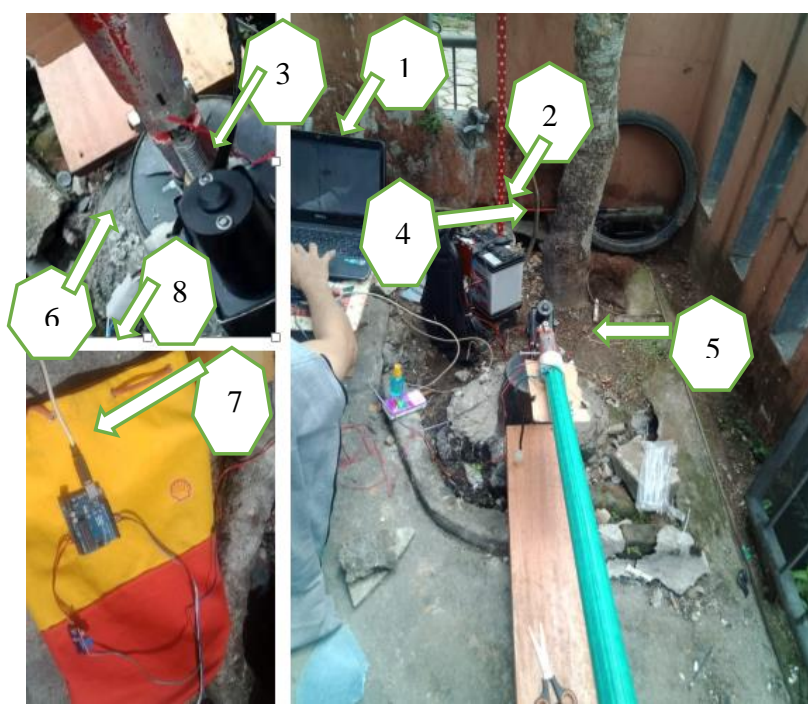

Gambar 3.1 Set-up alat

Keterangan gambar:

1. Laptop

2. Baterai

3. Motor listrik

4. Connecting joint

5. Batang

6. Strain gauge

7. Modul BF 350 AA

8. Arduino uno

\subsection{Pengukuran tegangan-regangan}

Hasil pengukuran yang ditampilkan serial monitor adalah nilai beda voltage (tegangan ADC), sehingga data tersebut harus dikonversikan ke dalam nilai regangan terlebih dahulu melalui persamaan 2.4 sebelum menjadi nilai tegangan dengan satuan mega pascal (MPa). Tabel 3.1 hingga 3.4 merupakan nilai tegangan ADC keluaran Arduino Uno yang dibaca oleh laptop.

Tabel 3.1 Data Hasil Pengukuran Tegangan pada ADC dengan variasi Derajat pada Connecting

\begin{tabular}{|c|c|c|}
\hline \multicolumn{3}{|c|}{ Joint otomatis } \\
\hline Derajat & $\begin{array}{c}\text { Analog Read } \\
\text { Rata-rata }\end{array}$ & $\begin{array}{c}\text { Tegangan } \\
\text { ADC (volt) }\end{array}$ \\
\hline $0^{0}$ & 16 & 0.078 \\
\hline 10 & 15.1 & 0.074 \\
\hline $20^{0}$ & 15 & 0.073 \\
\hline $30^{0}$ & 14.9 & 0.072 \\
\hline $40^{0}$ & 14 & 0.068 \\
\hline $50^{0}$ & 11.1 & 0.056 \\
\hline $60^{0}$ & 10 & 0.049 \\
\hline $70^{0}$ & 7.1 & 0.035 \\
\hline $80^{0}$ & 3.5 & 0.017 \\
\hline $90^{0}$ & 0 & 0 \\
\hline
\end{tabular}

Tabel 3.2 Data Hasil Pengukuran Tegangan pada ADC dengan variasi Derajat pada Connecting Joint manual lubang $1\left(90^{0}\right)$

\begin{tabular}{|c|c|c|}
\hline Derajat & $\begin{array}{c}\text { Analog Read } \\
\text { Rata-rata }\end{array}$ & $\begin{array}{c}\text { Tegangan } \\
\text { ADC }(\text { volt })\end{array}$ \\
\hline $0^{0}$ & 14.2 & 0.069 \\
\hline 10 & 13 & 0.063 \\
\hline $20^{0}$ & 11.5 & 0.056 \\
\hline $30^{0}$ & 9.8 & 0.048 \\
\hline $40^{0}$ & 8.7 & 0.042 \\
\hline
\end{tabular}




\begin{tabular}{|c|c|c|}
\hline $50^{0}$ & 7 & 0.042 \\
\hline $60^{0}$ & 5.4 & 0.026 \\
\hline $70^{0}$ & 3 & 0.017 \\
\hline $80^{0}$ & 2.1 & 0.01 \\
\hline $90^{0}$ & 0 & 0 \\
\hline
\end{tabular}

Tabel 3.3 Data Hasil Pengukuran Tegangan pada ADC dengan variasi Derajat pada Connecting Joint manual lubang $2\left(60^{\circ}\right)$

\begin{tabular}{|c|c|c|}
\hline Derajat & $\begin{array}{c}\text { Analog Read } \\
\text { Rata-rata }\end{array}$ & $\begin{array}{c}\text { Tegangan } \\
\text { ADC (volt) }\end{array}$ \\
\hline $0^{0}$ & 26 & 0.127 \\
\hline 10 & 25.4 & 0.124 \\
\hline $20^{0}$ & 24.1 & 0.117 \\
\hline $30^{0}$ & 22.7 & 0.11 \\
\hline $40^{0}$ & 21.5 & 0.104 \\
\hline $50^{\circ}$ & 20.5 & 0.099 \\
\hline $60^{0}$ & 20.3 & 0.098 \\
\hline
\end{tabular}

Tabel 3.4 Data Hasil Pengukuran Tegangan pada ADC dengan variasi Derajat pada Connecting Joint manual lubang $3\left(3^{\circ}\right)$

\begin{tabular}{|c|c|c|}
\hline Derajat & $\begin{array}{c}\text { Analog Read } \\
\text { Rata-rata }\end{array}$ & $\begin{array}{c}\text { Tegangan } \\
\text { ADC }(\text { volt })\end{array}$ \\
\hline $0^{0}$ & 34.4 & 0.167 \\
\hline 10 & 33.3 & 0.162 \\
\hline $20^{0}$ & 31.8 & 0.155 \\
\hline $30^{0}$ & 30.9 & 0.15 \\
\hline
\end{tabular}

Hasil data tegangan ADC yang di dapat dari laptop dilakukan pengolahan data menjadi nilai regangan $\varepsilon$ dengan menggunakan persamaan 2.4 Contoh pada $0^{0}$ di connecting joint otomatis.

$$
\begin{aligned}
\varepsilon & =\frac{4 V r}{G F(1+2 V r)} \\
& =\frac{4(0.0000345)}{2.14(1+2.0 .0000345)} \\
& =0.0000647
\end{aligned}
$$

Dimana:

$\mathrm{Vr}=[($ Vout $/$ Vin $)$ strained $-($ Vout - Vin $)$ unstrained $]$

$\mathrm{GF}=$ Gauge Factor $(2,14)$

$\varepsilon$ = Regangan

Nilai Vr diambil dari persamaan yang dihitung pada kondisi strained, dikarenakan kondisi awal sebelum pembebanan ialah 0 . Rumus mencari $\mathrm{Vr}$ mengacu pada rangkaian jembatan wheastone, maka nilai tegangan pada output ADC dibagi dengan nilai G (penguatan) yaitu sebesar 500, yang di dapat dari spesifikasi modul BF 350 AA dikali dengan tengangan yang masuk pada module BF 350 AA yaitu senilai 4,5 volt. Nilai $\operatorname{Vr}$ dapat diperoleh melalui persamaan 2.3 sebagai berikut:

$$
\begin{aligned}
V r & =\frac{\text { Vout }}{\text { Vin. } G} \\
& =\frac{0.078 \text { volt }}{4.5 \text { volt } .500} \\
& =0.0000345 \text { volt }
\end{aligned}
$$

Gambar 3.2 dan 3.3 merupakan gambar grafik regangan yang terjadi pada connecting joint otomatis dan manual. 


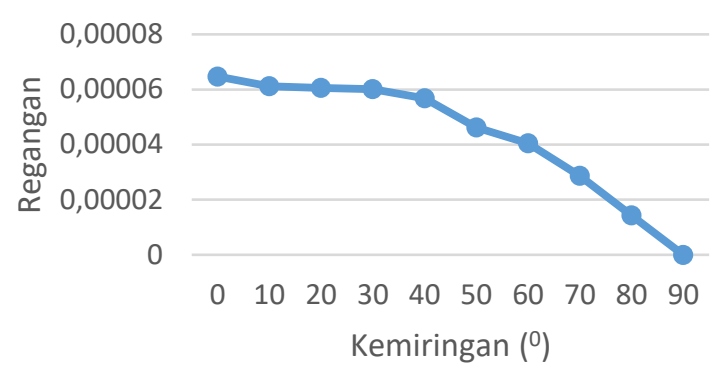

Gambar 3.2 Grafik Pengujian Regangan pada Connecting Joint Otomatis

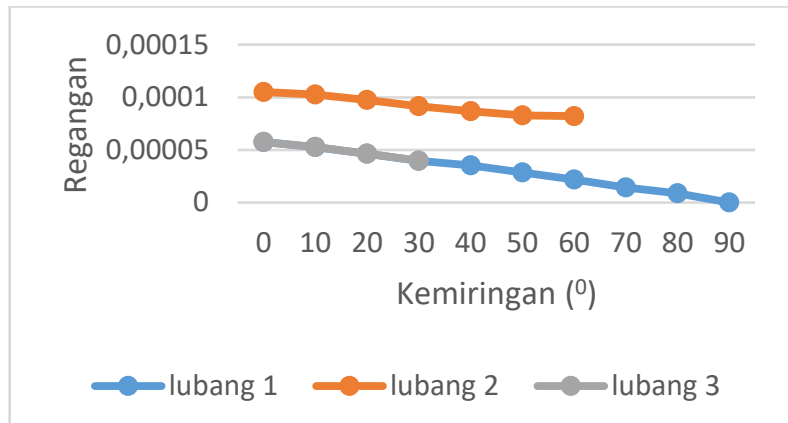

Gambar 3.3 Grafik Pengujian Regangan pada Joint Manual di lubang 1,2,dan 3

Setelah didapat hasil perhitungan regangan, selanjutnya menentukan tegangan dengan mengalikan nilai regangan dengan nilai dari modulus elastisitas dari alumunium yang didapat dari Tabel 3.5 yaitu senilai $69000 \mathrm{MPa}$

Tabel 3.5 Modulus Elastisitas Alumunium ${ }^{[9]}$

\begin{tabular}{|l|c|}
\hline \multicolumn{1}{|c|}{ Bahan } & Modulus elastisitas $\left(\times 10^{9} \mathrm{~N} / \mathrm{m}^{2}\right)$ \\
\hline Teflon & 0,5 \\
\hline Tulang manusia & 14 \\
\hline Kaca & $50-90$ \\
\hline aluminium & 69 \\
\hline Perunggu & $96-120$ \\
\hline Kuningan & $100-125$ \\
\hline tembaga & 117 \\
\hline besi & $190-210$ \\
\hline Baja & 200 \\
\hline intan & $1050-1210$ \\
\hline carbine & 32100 \\
\hline
\end{tabular}

Berikut merupakan contoh perhitungan tegangan pada connecting joint otomatis kemiringan $0^{0}$ dengan menggunakan persamaan 2.5 sebagai berikut:

$$
\begin{aligned}
\sigma & =\varepsilon \cdot E_{\text {alumunium }} \\
& =0.0000647 \times 69000 \mathrm{Mpa} \\
& =4.47 \mathrm{Mpa}
\end{aligned}
$$

Gambar 3.4 dan 3.5 merupakan gambar grafik tegangan yang terjadi pada connecting joint otomatis dan manual.

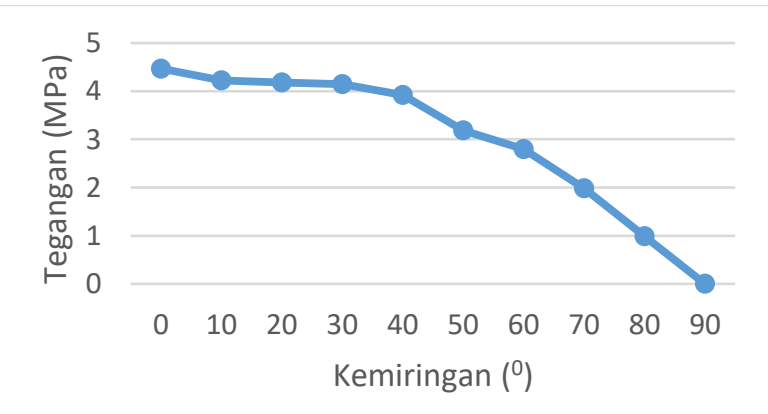

Gambar 3.4 Grafik Pengujian Tegangan pada Connecting Joint Otomatis 


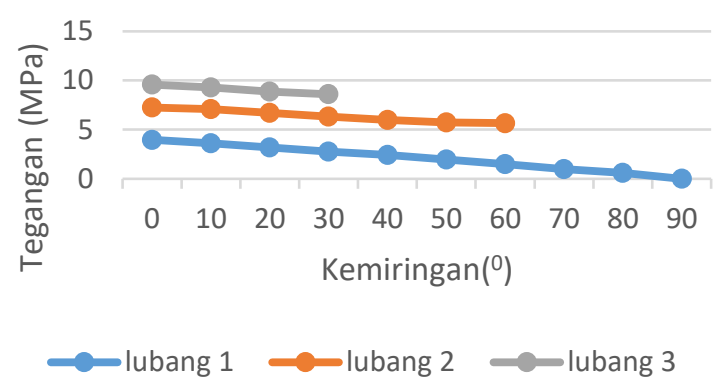

Gambar 3.5 Grafik Pengujian Tegangan pada Joint Manual di lubang 1,2,dan 3

Data pengukuran dan data simulasi tegangan dapat diperiksa dengan melakukan pembandingan. Data hasil simulasi tegangan didapat dari skripsi yang berjudul Analisa Komputasional Sifat Mekanik dan Faktor Keselamatan pada Connecting Joint Alat Pemanen Kelapa Sawit ${ }^{[10]}$. Perbandingan antara pengukuran tegangan regangan dengan simulasi dinyatakan dalam persentase error (\%error) sebagai berikut :

$$
\% \text { error }=\text { abs }\left\lfloor\frac{\sigma \text { simulasi }-\sigma \text { eksperimen }}{\sigma \text { simulasi }}\right\rfloor \times 100 \%
$$

Contoh pada saat kemiringan $0^{0}$ di connecting joint otomatis dengan menggunakan persamaan 3.1 berikut:

$$
\begin{aligned}
\text { \%error } & =\text { abs }\left[\frac{6.6-4.47}{6.6}\right\rfloor \times 100 \% \\
& =32.27 \%
\end{aligned}
$$

Hasil perhitungan tegangan yang telah dilakukan disajikan secara menyeluruh pada Tabel 3.6 hingga 3.9 berikut, dengan membandingkan data pengukuran dengan simulasi dinyatakan dalam \% error sebagai berikut :

Tabel 3.6 Perbandingan Data Hasil Pengujian dengan Data Hasil Simulasi pada Joint otomatis

\begin{tabular}{|c|c|c|c|}
\hline \multirow{2}{*}{ Derajat } & \multicolumn{2}{|c|}{ Tegangan (MPa) } & \multirow{2}{*}{ (\%) error } \\
\cline { 2 - 3 } & Eksperimen & Simulasi & \\
\hline $0^{0}$ & 4.47 & 6.6 & 32.27 \\
\hline 10 & 4.42 & 6.1 & 27.54 \\
\hline $20^{0}$ & 4.18 & 5.8 & 27.93 \\
\hline $30^{0}$ & 4.15 & 5.5 & 24.54 \\
\hline $40^{0}$ & 3.92 & 5.1 & 23.13 \\
\hline $50^{0}$ & 3.19 & 4.01 & 20.44 \\
\hline $60^{0}$ & 2.8 & 3.49 & 19.77 \\
\hline $70^{0}$ & 1.98 & 2.38 & 16.80 \\
\hline $80^{0}$ & 0.99 & 1.18 & 16.10 \\
\hline $90^{0}$ & 0 & 0.001 & 100 \\
\hline
\end{tabular}

Tabel 3.7 Perbandingan Data Hasil Pengujian dengan Data Hasil Simulasi pada Joint manual lubang 1

\begin{tabular}{|c|c|c|c|}
\hline \multirow{2}{*}{ Derajat } & \multicolumn{2}{|c|}{ Tegangan (MPa) } & \multirow{2}{*}{ (\%) error } \\
\cline { 2 - 3 } & Eksperimen & Simulasi & \\
\hline $0^{0}$ & 3.97 & 4.39 & 9.56 \\
\hline 10 & 3.63 & 4.32 & 15.97 \\
\hline $20^{0}$ & 3.21 & 4.12 & 22.08 \\
\hline $30^{0}$ & 2.75 & 3.80 & 27.63 \\
\hline $40^{0}$ & 2.43 & 3.35 & 27.46 \\
\hline $50^{0}$ & 1.96 & 2.81 & 30.24 \\
\hline $60^{0}$ & 1.5 & 2.18 & 31.19 \\
\hline $70^{0}$ & 0.98 & 1.44 & 31.94 \\
\hline $80^{0}$ & 0.6 & 0.00012 & 100 \\
\hline $90^{0}$ & 0 & & \\
\hline
\end{tabular}


Tabel 3.8 Perbandingan Data Hasil Pengujian dengan Data Hasil Simulasi pada Joint manual lubang 2

\begin{tabular}{|c|c|c|c|}
\hline \multirow{2}{*}{ Derajat } & \multicolumn{2}{|c|}{ Tegangan (MPa) } & \multirow{2}{*}{ (\%) error } \\
\cline { 2 - 3 } & Eksperimen & Simulasi & \\
\hline $0^{0}$ & 7.25 & 8.11 & 10.60 \\
\hline 10 & 7.09 & 8.04 & 11.81 \\
\hline $20^{0}$ & 6.73 & 7.82 & 13.93 \\
\hline $30^{0}$ & 6.32 & 7.49 & 15.62 \\
\hline $40^{0}$ & 5.99 & 7.03 & 14.79 \\
\hline $50^{0}$ & 5.72 & 6.48 & 11.72 \\
\hline $60^{0}$ & 5.67 & 5.83 & 2.74 \\
\hline
\end{tabular}

Tabel 3.9 Perbandingan Data Hasil Pengujian dengan Data Hasil Simulasi pada Joint manual lubang 3

\begin{tabular}{|c|c|c|c|}
\hline \multirow{2}{*}{ Derajat } & \multicolumn{2}{|c|}{ Tegangan (MPa) } & \multirow{2}{*}{$\begin{array}{l}(\%) \\
\text { error }\end{array}$} \\
\hline & Eksperimen & Simulasi & \\
\hline $0^{0}$ & 9.58 & 10.4 & 7.88 \\
\hline 10 & 9.29 & 10.33 & 10.06 \\
\hline $20^{0}$ & 8.87 & 10.13 & 12.43 \\
\hline $30^{\circ}$ & 8.6 & 9.81 & 12.33 \\
\hline
\end{tabular}

\section{KESIMPULAN DAN SARAN}

\subsection{Kesimpulan}

Berdasarkan penelitian serta analisa yang telah dilakukan maka penulis dapat menyimpulkan beberapa hal berikut:

1. Hasil yang diperoleh dari pengukuran regangan pada connecting joint manual dan otomatis ialah sebagai berikut:

$>$ Regangan tertinggi pada connecting joint manual sebesar 0.000128

$>$ Regangan terendah pada connecting joint manual sebesar 0

$>$ Regangan tertinggi pada connecting joint otomatis sebesar 0.0000647

$>$ Regangan terendah pada connecting joint otomatis sebesar 0

2. Hasil yang diperoleh dari pengukuran regangan pada connecting joint manual dan otomatis ialah sebagai berikut:

$>$ Tegangan tertinggi pada connecting joint manual sebesar $9.58 \mathrm{MPa}$

$>$ Tegangan terendah pada connecting joint manual sebesar $0 \mathrm{MPa}$

$>$ Tegangan tertinggi pada connecting joint otomatis sebesar $3.97 \mathrm{MPa}$

$>$ Tegangan terendah pada connecting joint otomatis sebesar $0 \mathrm{MPa}$

3. Persen error yang diperoleh dari hasil pengukuran tegangan secara eksperimental dan simulasi komputasional pada connecting joint manual dan otomatis sebagai berikut:

$>$ Persen error tertinggi pada connecting joint manual sebesar $100 \%$

$>$ Persen error terendah pada connecting joint manual sebesar $2,74 \%$

$>$ Persen error tertinggi pada connecting joint otomatis sebesar $100 \%$

$>$ Persen error terendah pada connecting joint otomatis sebesar $16,10 \%$

\subsection{Saran}

Dalam suatu penelitian pasti mengalami kendala dalam pengerjaannya. Dalam penelitian ini peneliti pun mengalami hal yang sama. Peneliti juga memiliki beberapa saran kepada peneliti selanjutnya demi terciptanya alat pemanen kelapa sawit yang lebih efisien dimasa depan. Adapun sarannya yaitu:

1. Dalam pengujian tegangan regangan dengan menggunakan modul BF 350 AA ini disarankan pada pembebanan yang relatif besar, dikarenakan keterbatasannya dalam membaca tegangan yang kecil.

2. Perlu memperhatikan cuaca dalam pengujian ini untuk menghindari adanya beban dinamis.

3. Disarankan pada penelitian selanjutnya menggunakan amplifier saat menggunakan sensor ini dalam pengujian tegangan dan regangan dengan pembebanan kecil. 


\section{REFERENSI}

[1] Safrudin, RA, 2018, Analisis Pengukuran Tegangan pada Struktur Pelat Berbasis Microcontroller Arduino, Jom FTEKNIK Volume 5, Universitas Riau Pekanbaru.

[2] Mulyati, 2010, Bahan Ajar Mekanika Bahan, Tegangan dan Regangan. ITP.

[3] Ramang, M, 2010, Penggunaan Strain gauge untuk Analisa Tegangan pada Pembebanan Statik Batang Aluminium, Skripsi, Jurusan Teknik Mesin, Palu.

[4] Budiman, 2010, Perhitungan Ekuivalen Stress Rangka Utama Sepeda Lipat

"Student Version" Menggunakan Strain Gauge dengan Kombinasi Konfigurasi 2 Gauge dan 4Gauge, Skripsi, Universitas Indonesia, Depok.

[5] Kyowa electronic instrument. Whats a strain gauge. (n.d). 3 november 2010. http: ei.co.jp/English/product/gauges/pdf/k gf- 01.pdf

[6] Kamirul, dkk. 2015. Rancang Bangun Data Logger Massa Menggunakan LoadCell. Prosiding SKF 2015: 211-215.

[7] Malik, Abdul. 2019. Rancang Bangun Sistem Pengukuran Regangan Tegangan Pada Alat Percobaan Batang Di Tumpuan Engsel Roll Menggunakan BF 350 AA. Skripsi, Universitas Muhammadiyah Malang.

[8] Figliola, Richard S and Beasley, Donald E. 2011. Theory and Design for MechanicalMeasurement, $5^{\text {th }}$ Edition. New Jersey: John willey \& Sons. Inc.

[9] Callister, Jr, William D dan rethwitsch, David G, 2009, Material science and engineering: An introduction, $8^{\text {th }}$ Edition, New Jersey: John Willey \& Sons, Inc.

[13] Manik, ABP, 2020, Analisa Komputasional Sifat Mekanik dan Faktor Keselamatan pada Connecting Joint Alat Pemanen Kelapa Sawit, Skripsi, Universitas Sumatera Utara, Medan. 